\title{
ИНСТИТУАЛИЗАЦИЯ ИННОВАЦИОННІХ СТРАТЕГИЙ: РЕТРОСПЕКТИВНІЙ БЕКГРАУНД
}

\begin{abstract}
Статья посвящена историческому обзору инноваџионных стратегий Александра Македонского и их превращению в институт, что обеспечило македонянам стратегические конкурентные преимущества и может быть использовано в современном управлении экономическими системами. Среди инновачионных направлений стратегического управления македонянами выделено техникотехнологические новации, политические, организаџионно-управленческие и экономические инновации. В процессе стратегического управления для мотиваџии армии и местного населения были применены методы фетита, мобильности и институт знаний.
\end{abstract}

Ключевые слова: инновация, инновациионые стратегии, институт, конкурентные преимущества, стратегическое управление.

Постановка проблемы. Современные тенденции экономического развития сконцентрированы на информации и инновациях, создающих радикальные конкурентные преимущества. Реальные возможности лидерского положения в гонке конкурентов получают актеры экономической деятельности, которые из сферы текущего управления переводят инновации в инструмент стратегического развития.

При всей позитивности инновационных действий возникает целая группа вызовов, которые необходимо учитывать в процессе стратегического управления. Так, инновации увеличивают неопределенность результатов, а, следовательно, и экономические риски, возникающие в процессе реализации инновационной стратегии. Кроме того, инновации требуют кадрового обеспечения как на этапе планирования, так и на стадиях реализации инновационных проектов. При этом стадия реализации инновационной стратегии или проекта предполагает необходимость наличия квалифицированных специалистов в двух сферах. Во-первых, в сфере стратегического управления, то есть принятия и реализации

(C) Кубиний Наталья Юрьевна, к.э.н., проф., проф. кафедры экономики предприятия ДВНЗ «Ужгородский национальный университет», г. Ужгород, тел.: +380506751412, e-mail: Natalya.kubiniy@uzhnu.edu.ua

Пулянович Елена Васильевна, к.э.н., доцент, доцент кафедры экономики Херсонского филиала Национального университета кораблестроения им. адм. Макарова, г. Херсон, тел.: 0669804969, еmail: lenapul@ukr.net

Косовилка Тамила Ивановна, аспирантка кафедры экономики предприятия ДВНЗ «Ужгородский национальный университет», Ужгород, тел.: +380508229132, e-mail: tamila.kosovilka@uzhnu.edu.ua решений. Во-вторых, специалистов, которые способны превратить новации в инновации и обеспечить экономический результат.

Ocобое значение приобретают вопросы взаимодействия экономической системы с внешней средой, которая должна быть готова к принятию предлагаемых инноваций.

Все это обуславливает актуальность научных изысканий и практической деятельности, связанных с инновационными стратегиями и их реализацией.

Обзор публикаций. Вопросам инновационных стратегий посвящены публикации многочисленных исследователей, что позволяет достаточно широко осветить их проблематику и охватить широкий спектр вопросов. Так, закарпатские авторы Микловда В.П., Шандор Ф.Ф. и др. (2014) рассматривают инновационные стратегии в контексте их потенциала: «інноваційний потенціал, який розглядається 3 системних позицій представляє собою можливості як інтеграційну взаємодію системних компонентів 3 певними формами прояву та факторами їх активізації». [6, с.104] Однако авторы не рассматривают, каким образом происходит активизация инновационного потенциала в процессе реализации инновационных стратегий.

Как инструмент конкурентоспособности страны рассматривает инновационные стратегии Юринець 3.В. (2016). Автор утверждает, что «прояв негативних тенденцій розвитку економіки України свідчить про відсутність системного підходу до управління інноваційним розвитком та процесами. Така ситуація ініціює питання формування інноваційної стратегії на всіх рівнях управління, що постане ефективним інструментом розроблення та втілення системи підвищення конкурентосрпоможності економіки країни для стимулювання іiі 
інноваційного та соціально-економічного розвитку». [7, с. 5] При этом вне поля зрения автора остаются аспекты, касающиеся эволюции инновационных стратегий, которая (эволюция) создает определенную культуру и правила поведения игроков на поле хозяйственной деятельности.

Значение инновационных стратегий раскрыто в публикации Лозовского О.М., Глуховой Н.Ю. [2013] следующим образом: «В нашому розумінні інноваційна стратегія, або стратегія інновацій, пропонує методи конкуренції та ведення бізнесу, задає напрями діяльності та розвитку на основі інновацій, а точніше інвестицій в інновації, 3 метою забезпечення конкурентоспроможності підприємства і на цій основі його тривалої прибутковості». [5]

Идеи упомянутых выше авторов, как и других исследователей инновационных стратегий, обходят вниманием проблемы становления стратегического управления, базирующегося на применении инноваций, что не позволяет установить эволюцию инновационных стратегий и определить их фундаментальные составные элементы.

Вследствие этого целью данной статьи является исследование исторических истоков инновационного стратегического управления, что позволит определить круг предложений современным стратегам, направленным на повышение эффективности стратегического менеджмента. Ограниченность объема статьи обусловила возможность остановиться лишь на инновационной стратегии Александра Македонского, одного из первых правителей, которому удалось реализовать свои управленческие амбиции на основе инновационных стратегий.

Результаты исследования. Одним из первых наиболее успешных стратегов человечество считает Александра Македонского, который превратил небольшую раздробленную страну в мирового лидера, овладел практически целым по тем временам миром. Важность институционального фактора в формировании стратегических инновационных преимуществ государства подтверждена всей жизнью и успехами Александра Македонского, который считается одним из величайшим и наиболее успешных стратегов в истории существования человечества. Создание основ инновационных стратегий принадлежит его отцу, македонскому царю Филиппу Второму, пришедшему к власти в маленькой стране, расположенной на севере Балканского полуострова среди варварских племен, отделенной от Греции горными хребтами. Роль Филиппа Второго в формировании не только инновационных стратегий, но и благодатной для их реализации среды раскрыта в публикации Кубиний Н.Ю. [4], которая выделила четыре направления реформаторской деятельности правителя, приведшие к созданию общества, способного принять стратегии Александра:

1. Организационные новации были направлены на сплоченность, мобильность и организованность армии Филиппа. Именно организационные инновации позволяют устанавливать институциональный базис дальнейших реформ, которые служат опережающему развитию страны и завоеванию лидирующей позиции в мире.

2. Организационные инновации были дополнены техническими новшествами, среди которых выделяют передвижные штурмовые башни, таран, механические снаряды и пр.

3. Внедрение инноваций охватило и социально-политический спектр македонской жизни. Князей Верхней Македонии, сопротивлявшихся Филиппу, он превратил в товарищей (эфиров) и поручил управлять отдельными военными подразделениями. Члены их родов стали активными участниками придворной жизни. Это создало социальный слой, который поддерживал деятельность царя и обеспечивал реализацию его целей.

4. Экономические новации позволили печатать собственные деньги и обеспечить относительно низкую стоимость ресурсов.

Таким образом, становление Александра как руководителя происходило уже в условиях жизни, проникнутых духом инновации, а инновационное управление приобретало институциональные черты.

Александр продолжил институализацию инновационных стратегий и их применение в указанных направлениях, что дало ему неоспоримые преимущества в борьбе за мировое господство.

Оставим за пределами данной публикации описание технических инноваций, которые достаточно широко известны современному исследователю, уделив внимание инновационным институтам в организационно-управленческой cфepe.

В организационных новациях отметим использование инсайдеров. Во время подготовки персидского похода Александр использовал такое преимущество, как наличие в рядах персов греческих наемников, считавшихся лучшими стратегами, а потому вызывавших ненависть персидских военных командиров. Это ограничивало мощность руководства армии персов, вносило дезорганизованность действий и разрозненность оперативных планов. Кроме 
этого, Александр уделял внимание созданию для персов логистических обструкций, нарушая поставки провианта в персидскую армию. Среди политических инноваций Александра Великого назовем привлечения туземцев к управлению на захваченных македонянами территориях. При этом вопрос армии и финансов Александр оставлял за греками и македонцами. Александр пытался заручиться поддержкой народов, ранее находившихся под властью персов. На свою сторону Великий привлекал культурные слои населения захваченных им народов. Во время оккупации Египта была отменена персидская система администрирования, а управление Верхним и Нижним Египтом передано двум египтянам. [1,2,3] Но и здесь финансы и армия были под контролем греков. Уникальным в управлении империей было сочетание местных азиатских законов с элементами демократии, которую Александр культивировал в Греции. Перерос свое время Александр и во взглядах на взаимоотношения между нациями собственной империи. В тот период царил императив Аристотеля, согласно которому варвар и раб по происхождению являлись понятиям идентичными. С момента рождения некоторые существа различаются в том отношении, что одни из них предназначены для подчинения, другие - для власти. Александр в противоречие с идеями Аристотеля и большинства греков, которые эти идеи разделяли, был сторонником равенства всех людей и вынашивал идеи мировой державы, народы которой были бы равноправными. Позже его идеи стали основой национальной политики ведущих государств мира.

Среди мотивационных институциональных составляющих стратегии Македонского выделим следующие:

1. Институт быстрых решений и непредвиденных действий в управлении. При Александре традицией становятся креативность, инновационность, непредсказуемость. Например, при переходе через пустыню, когда войско страдало от жажды, Александру поднесли шлем, наполненный водой. Полководец медленно выливает воду со словами: «Для одного слишком много, для всех - мало!». Также хорошо известен случай, когда Александру показали колесницу, принадлежавшую ранее царю Гордею. Ремень, которым прикреплялось дышло, был закручен в очень сложный узел. Существовала легенда, согласно которой человек, развязавший узел, будет господствовать в Азии. Александр сделал безуспешную попытку и понял, что это ему не удастся, а потому скомпрометирует его, пошатнет веру в него и будет истолковано как плохая примета. Император принял быстрое решение: выхватить меч и разрубить узел одним ударом.

2. Институт фетишизации. Фетиш, как известно, - это поклонение кому-либо или чемулибо. Фетиш используется в современных технологиях управления достаточно широко, а фетишизация начала проявляться еще в древние времена. Александр хорошо понимал значение формирования собственного имиджа как божества, посланца неба. С. Ковалев приводит пример: «Когда имя Александра прогремело по всему миру, вокруг его рождения появилось много легенд. Рассказывали, что отцом его был Зевс, который явился к Олимпиаде, матери Александра, в виде змея. ... В ту же ночь, когда родился на свет будущий завоеватель Азии, сгорел храм Артемиды. Его по легенде поджег Герострат. Пожар храма был представлен таким образом, что он предвещал рождение человека, который со временем сожжет весь Восток собственным пламенем» [3].

3. Институт знаний, опыта. Знание как часть общей культуры имели большое значение для личности Македонского и его государственной деятельности. Любовь к знаниям еще в юные годы привил ему Аристотель, занимавшийся по просьбе отца будущего стратега три года его воспитанием. Философ также привил большую любовь и уважение к греческой культуре. Именно это в будущем спасет Афины от разгрома после греческих выступлений против Александра и фивской катастрофы. В походе против персов свита Александра включала историков, философов, ботаников. Руководитель канцелярии Александра вел дневник, которой предоставил возможности историкам исследовать этот поход.

Совокупность рассмотренных направлений деятельности Александра Великого обеспечила македонянам создание таких конкурентных преимуществ, которые привели их к мировому политическому, военному и экономическому господству.

Выводы и перспективы дальнейших исследований. Исторический ракурс на применение инноваций в стратегическом управлении позволяет утверждать, что на формирование конкурентных преимуществ Македонии времен Александра значительно повлияли традиции, созданные отцом Александра, которые он настойчиво институализировал.

К таким направлениям, которые целесообразно учитывать современным стратегическим менеджерам всех уровней и 
преобразовывать из в институциональные нормы, относятся:

1. Технико-технологические инновации Александра Македонского, обеспечивающие скорость достижения оперативных целей при экономии ресурсов, в том числе и человеческих.

2. Политические новации, которые формируют благоприятную внешнюю среду для осуществления поставленных задач.

3. Организационно-управленческие инновации, которые мотивируют участников действий. K таким новациям отнесем институт мобильности решений и непредсказуемости действий, институт фетиша и институт знаний.

4. Экономические инновации, предполагающие нетрадиционные экономические решения.

Совокупность указанных направлений составляет основу инновационного стратегического управления, которое в свою очередь направлено на создание конкурентных преимуществ.

В процессе дальнейших исследований предполагается создать модель долгосрочных преимуществ экономической системы, базирующуюся на инновационных стратегиях.

\section{СПИСОК ИСПОЛЬЗОВАННЫХ ИСТОЧНИКОВ}

1. Green P. Alexander of Macedon B.C.: A Historical Biography / Green P. - Berkeley: University of California Press, 1991. - 356p.

2. O’Brien J. M. Alexander the Great: The Invisible Enemy / O’Brien J. M. - London; New York: Routledge, 1992. -364 p.

3. Ковалев С. И. Александр Македонський / С.И. Ковалев - М. : Интербук, 1990. - 110 с.

4. Кубіній Н.Ю. Витоки стратегічного управління: історичний ракурс інноваційного контенту стратегії Олександра Македонського / Н.Ю. Кубіній // Науковий вісник Полтавського університету економіки і торгівлі. Сер.: Економічні науки. - 2013. - № 1. - С. 350-355.

5. Лозовський О.М. Глухова Н.Ю. Особливості інноваційних стратегій як рушійного фактору розвитку інновацій на підприємствах/О.М. Лозовський, Н.Ю. Глюхова// Nauka.Zinet.Info. - 2013 - Электронный ресурс. Режим доступа: http://nauka.zinet.info/23/gluhova.p

6. Стратегічний потенціал економічної системи: інноваційні та інституціональні механізми його активізації: монографія / Мікловда В.П., Шандов Ф.Ф., Кубіній Н.Ю., Мошак С.М., Шеверя М.Ю., Кубіній В.В. - Ужгород. - 2014. - 420c.

7. Юринець 3.В. Інноваційні стратегії в системі підвищення конкурентоспроможності України: дисертація на здобуття наукового ступеня д-ра економ. наук: спец. 08.00.03 / Юринець Зорина Володимирівна - Львів : Львівський національний університет ім. І.Франка, 2016. - 518c.

\section{REFERENCE}

1. Green P. (1991) Alexander of Macedon B.C.: A Historical Biography / Green P. - Berkeley: University of California Press.

2. O’Brien J. M. (1992) Alexander the Great: The Invisible Enemy / O'Brien J. M. - London; New York: Routledge.

3. Kovalev S. I. (1990) Aleksandr Makedonski [Aleksandr Makedonski]. - M: Interbuk. [in Russian].

4. Kubinij N. Yu. (2013). Vytoky stratehichnoho upravlinnia: istorychnyj rakurs innovatsijnoho kontentu stratehii Oleksandra Makedons'koho [The origins of strategic management: a historical perspective of the innovative content of Alexander Macedonian's strategy]. Naukovyj visnyk Poltavs'koho universytetu ekonomiky i torhivli. Ser.: Ekonomichni nauky. - Poltava University of Economic and Trade. Ser. Economical Researches, 1, .350-355. [in Ukranian].

6. Miklovda V.P., Shandov F.F., Kubiniy N.Yu., Moshak S.M., Sheverya M.Yu., KubInIy V.V. (2014). StrategIchniy potentsIal ekonomIchnoYi sistemi: InnovatsIynI ta InstitutsIonalnI mehanIzmi yogo aktivIzatsIYi: monograflya [ Strategic Potential of the Economic System: Innovation and Institutional Mechanizms of Activization]. Uzhgorod. [in Ukranian].

7. Yurinets Z.V. (2016). InnovatsIynI strategiyi v sistemI pIdvischennya konkurentospromozhnostI Ukrainy. [Innovation Strategies in a System of Competitive Growth]. Doctor's thesis - Lviv: Lviv National University named after I.Franko [in Ukranian]. 